\title{
Ulik praksis for godkjenning av utdanning
}

Migranter fra EU-land har lettere for å få godkjent utdanningen sin selv om de kan lite norsk. For migranter utenfra EU er veien til autorisasjon mye lengre.

\section{Forfatter}

\section{Mai Camilla Munkejord}

Forsker I og professor

Uni Research Rokkansenteret og UiT, Norges Arktiske Universitet

\section{Nøkkelord}
migranter
Autorisasjon
EU
Internasjonalt samarbeid

Sykepleien 2017 105(6)(44-47)

DOI: https://doi.org/10.4220/Sykepleiens.2017.62137

\section{HOVEDBUDSKAP}

Migranter som har flyttet til Finnmark, og som i dag jobber som helsefagarbeidere, sykepleiere og leger, har ulike erfaringer med å få godkjent utdanningen sin. Særlig migranter fra land utenfor EU har ikke fått godkjent sin helsefaglige utdanning fra hjemlandet og jobber i dag i stillinger de er overkvalifiserte for. Andre med utdanning fra en godkjent institusjon innenfor EU har fått autorisasjon til å utføre yrket sitt i Norge uten å kjenne det norske helsevesenet eller kunne noe særlig norsk. Begge deler representerer en utfordring for den norske helse- og omsorgssektoren. 
Pleie- og omsorgssektoren i Norge har slitt med rekrutteringen siden 1990-tallet $(1,2)$. Her utgjør innvandrere en stadig viktigere gruppe. Av en årlig vekst på rundt 1000 sykepleiere de siste årene står sykepleiere med innvandrerbakgrunn for om lag 40 prosent (3). Til tross for den økende andelen og betydningen av migranter i kvalifisert helse- og omsorgsarbeid i hele Norge har relativt lite blitt skrevet om denne gruppen, med unntak av noen få, men viktige studier $(1,2,4-7)$.

Internasjonalt er temaet langt mer diskutert, særlig med et kritisk blikk på omsorgsrelasjoner. De har også vært opptatte av hvordan man kan oppnå god kvalitet $\mathrm{i}$ pleie- og omsorgssektoren til tross for trange budsjetter samt språk- og kulturforskjeller mellom pleiere og brukere (8-11).

Riemsdijk (1) skriver om erfaringene til sykepleiere som kom til Norge fra Polen på begynnelsen og midten av 2000-tallet. Utgangspunktet den gangen var at Aetat hadde fått i oppdrag fra Arbeidsdepartementet å rekruttere kvalifisert helsepersonell, deriblant sykepleiere fra Polen (1). Det ble så satt kriterier som gjorde at kun kandidater med mastergrad fra Polen fikk autorisasjon til å jobbe som sykepleiere i Norge.

Statens autorisasjonskontor for helsepersonell (SAFH) er et viktig organ som skal bidra til at vi unngår marginalisering av kvalifiserte innvandrere på arbeidsmarkedet i Norge. Personer med utdanning fra EU får automatisk autorisasjon til å arbeide i Norge dersom vedkommende har et vitnemål fra en institusjon godkjent av EU. Øvrige kandidater får søknaden sin vurdert individuelt. Dersom SAFH oppdager en mangel på et bestemt område, må søkeren ta kurs eller tilleggsutdanning.

\section{Hensikt med studien}


Jeg intervjuet til sammen 18 innvandrere ansatt i stillinger som tilkallingsvikarer, helsefagarbeidere, sykepleiere, leger og psykologer i henholdsvis eldreomsorgen og psykiatrien eller miljøtjenesten.

I denne artikkelen har jeg valgt å analysere erfaringene til de sju informantene som var utdannet lege eller sykepleier i sitt hjemland, og som i dag jobber som helsefagarbeidere, sykepleiere og leger i Norge (tabell 1). Jeg fokuserer på deres erfaringer med akkreditering og kvalifisering til norsk helse- og omsorgssektor. Jeg vil særlig legge vekt på møtene deres med SAFH. Akkreditering er å søke om å få utdanningen sin fra hjemlandet godkjent. Kvalifisering handler om de grepene som gjøres i Norge for å få godkjenning på plass - for eksempel at de må ta mer utdanning eller ny praksisperiode.

Jeg ønsket også å studere migrantenes fortellinger om egen arbeidshverdag, der de fokuserte på blant annet oppgaver, ansvar, kompetanse i norsk språk og forståelse av «god omsorg».

\begin{tabular}{|c|c|c|c|c|}
\hline $\begin{array}{l}\text { Navn, alder } \\
\text { landbakgrunn }\end{array}$ & $\begin{array}{l}\text { Migrasjonsbak- } \\
\text { grunn, antall ări } \\
\text { Finnmark/Norge }\end{array}$ & $\begin{array}{l}\text { Utdanning } \\
\text { Godkjent av SAFH? }\end{array}$ & $\begin{array}{l}\text { Helsefaglig } \\
\text { utdanning tatt } \\
\text { iNorge }\end{array}$ & Stilling \\
\hline $\begin{array}{l}\text { Bogdan (35), } \\
\text { Ost-Europa }\end{array}$ & $\begin{array}{l}\text { Arbeidsmigrant } \\
\text { (5 ár, kom direkte til } \\
\text { Finnmark). }\end{array}$ & Er utdannet lege ihjemlandet. & $\begin{array}{l}\text { Har tatt } \\
\text { spesialisering } \\
\text { iNorge. }\end{array}$ & $\begin{array}{l}\text { Lege, fast } \\
\text { stilling, heltid. }\end{array}$ \\
\hline $\begin{array}{l}\text { Dragoslava, (45), } \\
\text { Sør-Europa }\end{array}$ & $\begin{array}{l}\text { Arbeidsmigrant } \\
\text { ( } 2 \text { år, kom direkte til } \\
\text { Finnmark). }\end{array}$ & $\begin{array}{l}\text { Er utdannet sykepleier ihjemlandet. Fikk } \\
\text { utdanningen gookkjent før ankomst til Norge. }\end{array}$ & & $\begin{array}{l}\text { Helsefagarbeider på } \\
\text { sykehjem. Litt over } 20 \\
\text { prosent fast stilling + } \\
\text { ekstravakter. }\end{array}$ \\
\hline $\begin{array}{l}\text { Evelyn (32), } \\
\text { Afrika }\end{array}$ & $\begin{array}{l}\text { Arbeidsmigrant } \\
\text { (5,5åri Norge, } \\
\text { nesten } 2 \text { åri } \\
\text { Finnmark). }\end{array}$ & $\begin{array}{l}\text { Legeutdannet i EU. } \\
\text { Oppnådd autorisasjon etter flere års innsats } \\
\text { fordi hun manglet godkjent turnus ved ankomst } \\
\text { til Norge. }\end{array}$ & $\begin{array}{l}\text { Holder på med } \\
\text { spesialisering. }\end{array}$ & Lege, fast stilling, heltid. \\
\hline $\begin{array}{l}\text { Jelena (50), } \\
\text { Russland }\end{array}$ & $\begin{array}{l}\text { Ekteskapsmigrant } \\
\text { (13år, kom direkte til } \\
\text { Finnmark). }\end{array}$ & $\begin{array}{l}\text { Barnelegeutdannet i Russland. } \\
\text { Godkjent lege i Norge etter flere års arbeid med } \\
\text { kurs, eksamener og ny turnus. }\end{array}$ & $\begin{array}{l}\text { Har tatt } \\
\text { spesialisering i } \\
\text { Norge. }\end{array}$ & Lege, fast stilling, heltid. \\
\hline $\begin{array}{l}\text { Kattrina (45), } \\
\text { Russland }\end{array}$ & $\begin{array}{l}\text { Ekteskapsmigrant } \\
\text { (1larr, kom direkte til } \\
\text { Finnmark). }\end{array}$ & $\begin{array}{l}\text { Utdannet barnelege i Russland. } \\
\text { Fikk ikke godkjent legeutdanningen av SAFH, } \\
\text { har ikke forsokt å ta tilleggseksamener og kurs. }\end{array}$ & $\begin{array}{l}\text { Utdannet } \\
\text { sykepleier i Norge. }\end{array}$ & $\begin{array}{l}\text { Sykepleier, } 100 \text { prosent fast } \\
\text { stilling, turnus. }\end{array}$ \\
\hline $\begin{array}{l}\text { Ludmila (45), } \\
\text { Russland }\end{array}$ & $\begin{array}{l}\text { Ekteskapsmigrant } \\
\text { (13år, kom direkte til } \\
\text { Finnmark). }\end{array}$ & $\begin{array}{l}\text { Utdannet jordmor i Russland. } \\
\text { Godkjent sykepleier i Norge etter en del kurs, } \\
\text { eksamener og ny turnus. }\end{array}$ & $\begin{array}{l}\text { Hartatten del } \\
\text { kursi ledelsei } \\
\text { Norge. }\end{array}$ & $\begin{array}{l}\text { Sykepleier, } 70 \text { prosent fast } \\
\text { stilling på sykehiem + } \\
\text { tilkallingsvikar. }\end{array}$ \\
\hline $\begin{array}{l}\text { Margaretta (40), } \\
\text { Russland }\end{array}$ & $\begin{array}{l}\text { Ekteskapsmigrant } \\
\text { (5 ̊år,kom direktetil } \\
\text { Finnmark). }\end{array}$ & $\begin{array}{l}\text { Bachelor i humanistiske fag + sykepleierutdan- } \\
\text { net i Russland. } \\
\text { Kun autorisasjon som helsefagarbeider i Norge. }\end{array}$ & $\begin{array}{l}\text { Hart tatt noen kurs } \\
\text { iNorge. }\end{array}$ & $\begin{array}{l}\text { Helsefagarbeider. } \\
\text { Kombinerer to deltidsstil- } \\
\text { linger på to arbeidsplasser. }\end{array}$ \\
\hline
\end{tabular}

\section{Metode}


Før datainnsamlingen startet, ble prosjektet sendt inn og godkjent av Norsk senter for forskningsdata (NSD). Datamaterialet er produsert gjennom en kvalitativ intervjustudie jeg gjorde våren 2015 i Finnmark. I Finnmark er nesten 10 prosent av befolkningen migranter fra land som Russland, Finland, Polen, Litauen, Sverige, Thailand, Afghanistan, Somalia og Nepal. Andelen innvandrere som jobber i helse- og omsorgssektoren, er imidlertid dobbelt så høy, altså 20 prosent, ifølge ferske tall fra Statistisk sentralbyrå (12).

Ledere i helse- og omsorgssektoren i Finnmark hjalp til med å identifisere informantene. Jeg fikk også hjelp via mine personlige nettverk i regionen etter å ha bodd der i åtte år. Jeg ønsket å oppnå variasjon i migrasjonsbakgrunn, alder, familiesituasjon, utdanning og arbeidslivserfaringer.

Min analytiske tilnærming til informantenes fortellinger er inspirert av narrative og fortolkende perspektiver (13-14). Målet med intervjuene var å få tak i beskrivelser av hvordan den intervjuede forsto norsk arbeidsliv og arbeidshverdagen etter inntreden $\mathrm{i}$ arbeidslivet. Deretter ville jeg tolke de beskrevne fenomenene. Jeg ønsket med andre ord å forstå verden slik den tar form sett fra informantenes ståsted. Hensikten var å få frem kunnskap om hvordan de oppfatter seg selv innen de omskiftelige sosiokulturelle rammene for hverdagslivet deres (15).

\section{Resultater}

Det er store variasjoner i informantenes utdanningsbakgrunn og i hvilken grad de i dag jobber i stillinger som matcher deres utdanningsnivå. Noen av informantene, Dragoslava og Margaretta, er utdannet sykepleiere i hjemlandet, men jobber i dag som helsefagarbeidere. Dragoslava sier at med hennes utdanning fra et land i Øst-Europa kunne man tidligere jobbe som sykepleier i Norge: 
«Vi hadde de samme fagene som sykepleierne her i

Norge, men utdanningen min ble ikke godkjent som

sykepleierutdanning av SAFH.»

\section{«Noen av informantene er utdannet sykepleiere i hjemlandet, men jobber i dag som helsefagarbeidere.»}

Et par år tidligere hadde sykepleiere fra hennes

hjemland motsatt erfaring da de søkte om

akkreditering. Margaretta på sin side forteller:

«Jeg fikk ikke autorisasjon som sykepleier da jeg kom

til Norge ettersom Russland er utenfor EU. Så jeg ble bare godkjent som helsefagarbeider. De sa i SAFH at jeg måtte ta hele utdanningen på nytt.»

Intervjuer: «Hva tenker du om det?»

Margaretta: «Jeg mener at de kunne tilbudt ekstrautdanning og mulighet til å ta eksamen på nytt her [i Finnmark]. Jeg skrev et brev om det til Helsedirektoratet der jeg forslo dette. Jeg er enig i at det trengs tilleggsutdanning og språktest for oss som kommer utenfra EU. Jeg skjønner det veldig godt, men de burde ordnet med alternative måter å få autorisasjonen på. Det var litt vanskelig, særlig fordi reglene endrer seg over tid, slik at de sykepleierne [fra Russland, med samme utdanning] som kom fem år før meg, de fikk autorisasjon etter å ha tatt ekstra praksis og bestått noen tester.»

\section{Kurs og tilleggseksamener}

Ludmila, som i likhet med Margaretta er utdannet sykepleier i Russland, kom til Norge nettopp noen år tidligere og fikk etter hvert godkjent sin sykepleierutdanning. Men helt enkelt var det ikke. Ludmila forteller: 
«Etter at jeg kom hit, så søkte jeg om å få godkjent sykepleierutdanningen. Jeg sendte alle papirene til akkrediteringskontoret, men jeg fikk ikke utdanningen godkjent ettersom den var tatt i et land utenfor EU. Så jeg fikk en oversikt over fag jeg måtte ta opp igjen: Det var praksis, medikamentdosering og et par ting til. Så selv om jeg hadde jobbet i mange år, mente de at jeg måtte ha praksis i Norge. Det var litt sånn 'ja, hvorfor det?'. Men samtidig så jeg at det var en trygghet både for dem og for meg å måtte gå gjennom det.»

Etter å ha tatt de nødvendige kursene og tilleggseksamenene måtte Ludmila betale 18000 kr for å få praksisplass. Hun utdyper:

«Det var tøft, for jeg hadde lite penger. Jeg ville jo jobbe for å tjene penger, men så måtte jeg ta eksamener først, og så praksis som jeg selv måtte betale for ... alt det der. Så jeg husker at jeg jobbet nesten 24 timer i døgnet i den perioden. Jeg måtte til Hammerfest for å følge undervisninga, jeg måtte ta alle vaktene jeg fikk, nattevakt, eller hva som helst ... Det var en slitsom periode!»

\section{Lege ble sykepleier}

To av informantene i studien er utdannet barneleger i Russland. Én av dem, Kattrina, jobber som sykepleier i dag. Hun kom til Norge som ekteskapsmigrant og fikk sitt første barn etter et par år i Norge. Hennes norske mann hadde en tidkrevende jobb.

Kattrina hadde ikke mulighet til å reise til Oslo i mange runder over flere år for å ta nødvendige kurs og eksamener - for så å prøve å få legeutdanningen godkjent i Norge. I stedet valgte hun etter hvert å utdanne seg til sykepleier, blant annet fordi dette var et lokalt utdanningstilbud som hun kunne ta uten å måtte reise bort fra barnet. Samtidig jobbet hun som assistent i miljøtjenesten. Hun utdyper: 
«Jeg gikk jo fra å være barnelege til å være sykepleier, så jeg føler meg veldig trygg på sykepleierjobben

[latter]. ... Det er mange som har spurt meg om hvorfor jeg tok sykepleierutdanningen. Jeg kunne tatt eksamener for å få godkjent barnelegeutdanningen, men jeg bestemte meg for å ikke gjøre det. ... Jeg måtte egentlig velge mellom å være mor eller ta deler av utdanningen på nytt for å bli lege i Norge. Da valgte jeg familien. Når utdanningen er tatt i et land utenfor EU, så er det helt andre krav for godkjenning selv om jeg hadde mange års erfaring. Det føltes litt urettferdig.»

\section{三 «Jeg gikk jo fra å være barnelege til å være sykepleier, så jeg føler meg veldig trygg på sykepleierjobben [latter].»}

\section{Kattrina fra Russland}

Kattrina forteller at hun synes at

sykepleierutdanningen var relativt krevende fordi mange behandlingsmetoder hadde endret seg fra den gangen hun tok legeutdanningen i Russland. Dessuten lærte hun norsk språk. Hun lærte også om norsk kultur og om det norske helsevesenet i de tre årene sykepleierutdanningen varte, noe hun synes var positivt og nyttig.

\section{Tøft å få autorisasjon}

Jelena, som også er utdannet barnelege i Russland, valgte i motsetning til Kattrina å reise til Oslo en rekke ganger for å ta de ekstra eksamenene som krevdes for at hun etter hvert skulle få autorisasjon til å jobbe som lege i Norge. Prosessen viste seg å bli lang og krevende: Det tok henne til sammen fem år å lære seg tilstrekkelig godt norsk, gjennomføre alle de obligatoriske kursene og ta tilhørende eksamener i Oslo samt gjennomføre en ny turnusperiode i Norge. Ved siden av dette kvalifiseringsløpet jobbet hun deltid som assistent på et helsesenter. Jelena forteller: 
«Ja, altså, det var helt uventet at det norske samfunnet tvilte på min utdannelse, og at jeg ble sendt på forpraksis for å se om jeg klarte å fungere som lege. Det var nedverdigende.»

Samtidig sier hun:

«Men til syvende og sist, selv om det kunne vært færre eksamener, så angrer jeg ikke på at jeg fikk muligheten til å jobbe som assistent, eller på at jeg var igjennom ny turnustjeneste i Norge. Det ga meg mulighet til å lære systemet på en annen måte. For helsesystemet, det er forbundet med Nav, med det sosiale systemet, og det er så kompliserte greier, at med bare tre måneders språkkurs [som er situasjonen for en del leger utdannet innenfor EU], så har man ingen mulighet til å kunne klare seg som lege i Norge på en ok måte.»

\section{Lettere fra EU-land}

Bogdans fortelling utdyper det Jelena snakker om. Bogdan er utdannet lege i EU og fikk jobb som fastlege i Finnmark gjennom et rekrutteringsbyrå. I forkant av dette jobbtilbudet tok han og konen Brigida, som også har høyere utdanning på et annet fagfelt, et 60-timers norskkurs i hjemlandet. Deretter dro paret til Norge, hvor Bogdan startet i fastlegejobben etter få dager.

Intervjuer: «Hva? Begynte du rett på jobb? Men ... Du kan engelsk»?

Bogdan: «Ja, men det hjalp ikke så mye. ... Jeg husker veldig definerte trinn i språkutviklingen min: De første tre-fire ukene var det sånn at jeg prøvde å ikke spy av stress i dusjen på morgenen før jeg gikk på jobb, det var første trinn. Deretter var det to-tre-fire måneder av neste trinn som gikk over da jeg ikke lenger fikk klump i magen når jeg måtte svare på telefon.»

Brigida: «Ja, det var neste steg [latter].» 
Bogdan forteller at det gikk noenlunde bra på jobben etter et halvt års tid. Men hele det første året $\mathrm{i}$ fastlegejobben jobbet han sju dager i uken, hele dagen til langt på kveld. Brigida hjalp ham med alt hun kunne:

Brigida: «Vi brukte all fritid på jobben hans, vi kunne sitte der til klokka to om natten.»

Intervjuer: «For du hjalp ham?»

Brigida: «Ja, jeg hjalp.»

Bogdan: «Med diverse skjemaer og henvisninger, det å lese, forstå, ikke overse noe, finne rett skjema ... Selvsagt så hun ikke på ting som handlet om konkrete pasienter, men hun hjalp meg med språket og det praktiske. ... Jeg var på jobb nesten hver eneste dag hele det første året. For å lese, skrive, forstå og egentlig bare for å klare arbeidsmengden. ... For det var mange skjemaer, bestillinger, henvisninger, hva som er mulig å ordne lokalt, hva som må sendes til Hammerfest, Tromsø, andre steder, trygdesøknader, legeerklæringer, sykmeldinger, resepter ...»

\section{三 «Bogdans historie viser at leger fra et EU- land ikke trenger å ta noen norskeksamen før de begynner å behandle pasienter.»}

Bogdans historie viser at leger fra et EU-land ikke trenger å ta noen norskeksamen før de begynner å behandle pasienter. Som Bogdan uttrykker det: «Det var bare forventet at vi skulle kunne språket.» Autorisasjonen fikk han uten tilleggsspørsmål.

\section{Diskusjon}


De offentlige omsorgstjenestene slik vi kjenner dem i dag, har ifølge Melding til Stortinget nr. 29 (16) en kort historie: På førti år har pleie- og omsorgssektoren i Norge vokst fra vel 20000 årsverk til mer enn 120 000 årsverk. Fra i hovedsak å være et tilbud til eldre er omsorgstjenesten i dag et tilbud til brukere i alle aldersgrupper. Brukerne har et mangfold av diagnoser, funksjonsnedsettelser og tilstander.

Som nevnt innledningsvis har pleie- og omsorgssektoren lenge slitt med sviktende rekruttering. Både blant forskere og politikere ser vi en økende interesse for innvandreres rolle i pleie- og omsorgssektoren i ulike deler av verden (4, 9-11).

Denne artikkelen har belyst erfaringene med akkreditering og kvalifisering blant migranter som har flyttet til Finnmark, og som i dag jobber som helsefagarbeidere, sykepleiere og leger. Studien viser at informantene har ulike erfaringer med SAFH. Noen som ikke har fått godkjent sin helsefaglige utdanning fra hjemlandet, jobber i dag i stillinger som de er overkvalifiserte for. Dette gjelder sykepleiere som i dag jobber som helsefagarbeidere, og leger som arbeider som sykepleiere.

\section{¿ «Flere synes at det er litt nedverdigende at det norske samfunnet ikke har tillit til kvaliteten av og innholdet $i$ utdanningen fra hjemlandet deres.»}


Noen har fått utdanningen sin godkjent, men først etter flere år med norskopplæring, kurs, tilleggseksamener og ny turnustjeneste. Flere synes at det er litt nedverdigende at det norske samfunnet ikke har tillit til kvaliteten av og innholdet i utdanningen fra hjemlandet deres. Samtidig påpeker disse informantene at et langt og krevende kvalifiseringsløp i Norge tross alt har gitt dem muligheten til å lære om det norske helse- og sosialsystemet. Ikke minst har det gitt dem tid og mulighet til å heve sin kompetanse i norsk språk, som har vært nyttig i deres nåværende yrkeskarriere.

Andre derimot, med utdanning fra en godkjent institusjon innenfor EU, har fått autorisasjon til å utføre yrket sitt i Norge uten å kjenne det norske helsevesenet og uten nødvendigvis å kunne noe særlig norsk. Disse informantene forteller at de fikk en så tøff start i det norske helsevesenet at de i lang tid bare så vidt klarte å komme seg gjennom arbeidsdagen uten å knekke sammen.

\section{Kjønnsroller}

Man kan spørre seg om hvorvidt kjønn og forpliktelser på hjemmebane kan bidra til å forklare noen av funnene i denne studien. For eksempel ser vi at den mannlige legen, Bogdan, får enorm hjelp og støtte fra sin kone i starten av karrieren. Hun hjelper ham med å klare seg i jobben når han får autorisasjon som lege i Norge uten å ha kompetanse verken i norsk språk eller norsk helsesystem. Flere av de kvinnelige informantene, som Kattrina, fikk på langt nær den samme støtten og hjelpen fra sine ektefeller. 
Mens noen informanter har opplevd at det norske samfunnet tviler på deres fagkompetanse, forteller flere samtidig at et langt kvalifiseringsløp har vært nyttig for å utvikle kompetansen i norsk språk samt lære mest mulig om norsk helsesektor. Flere peker dessuten på at det stadig kommer nye diagnoser og behandlingsmetoder, og at forståelsen av hva som er riktig diagnose og behandlingsmåte, kan variere fra ett land til et annet.

Disse funnene tilsier at helse- og omsorgsfeltet ikke bare er faglig, men også sosiokulturelt fundert. Resultatene peker således på hvor viktig det er å kontinuerlig kunne tilby kurs og etterutdanning til de ansatte i en stadig mer kompleks helse- og omsorgssektor. Slike kurs og etterutdanninger bidrar til å sikre pasientsikkerhet, rutiner og kvalitet i tjenestene som tilbys.

\section{Desentralisert ordning?}

Det er viktig å være pragmatisk og løsningsorientert i dagens situasjon med økt omsorgsbehov kombinert med stadig høyere andel migranter blant de ansatte i helse- og omsorgssektoren. Målet må være å bedre verdsette og ta i bruk den kompetansen kvalifisert helse- og omsorgspersonell med innvandrerbakgrunn representerer.

For mange sykepleiere og leger med innvandrerbakgrunn som bor i distriktene, kan det å reise til Oslo for lengre perioder om gangen være dyrt og praktisk vanskelig å gjennomføre, ikke minst fordi mange har omsorgsforpliktelser på hjemstedet. En desentralisert godkjenningsordning kan være løsningen. 
Kunne det vært mulig med en desentralisert godkjenningsordning der for eksempel sykepleiere med ikke-godkjent utdanning fra hjemlandet får tilbud om lønnet praksisplass i seks til ni måneder på sitt nåværende bosted? Slik lønnet praksis kunne vært etterfulgt av et tilbud om å ta eksamen i norsk språk samt en praktisk og teoretisk eksamen i noen av de mest sentrale sykepleiefagene.

Og kunne man tenkt seg tilsvarende ordninger for andre relevante helse- og omsorgsfaglige yrkesgrupper? Da ville kandidatene i det minste sluppet å selv måtte finansiere dyre og tidkrevende opphold i Oslo i de årene de jobber med å få utdanningen sin godkjent i Norge. Samtidig ville norsk helse- og omsorgssektor i større grad enn det som er tilfellet i dag kunne få benytte deres ettertraktede fagkompetanse.

\section{Referanser}

1. Riemsdijk Mv. Rekruttering av polske sykepleiere til Norge. Erfaringer og virkninger. Fafonotat 2006:27. Oslo: FAFO Østforum; 2006.

2. Isaksen LW. Transnational Spaces of Care: Migrant nurses in Norway. Social Politics. 2012;19(1):58-77.

3. Aamodt PO, Høst H, Arnesen CÅ, Næss T. Evaluering av Kompetanseløftet 2015.

Underveisrapport 3. Oslo: NIFU; 2011.

4. Christensen K, Guldvik I. Migrant care workers: Searching for new horizons. Farnham, Burlington: Ashgate; 2014.

5. Isaksen LW. Introduction: Global care work in Nordic societies. I: Isaksen LW (red.). Global Care Work: Gender and migration in Nordic societies. Lund: Nordic Academic Press; 2010. 
6. Riemsdijk Mv. Neoliberal reforms in elder care in Norway: Roles of the state, Norwegian employers, and Polish nurses. Geoforum. 2010;41(6):930-9.

7. Riemsdijk Mv. Everyday geopolitics: the valuation of labour and the socio-political hierarchies of skill: Polish nurses in Norway. Journal of Ethnic and Migration Studies. 2013;39(3):373-90.

8. Bourgeault IL, Atanackovic J, Rashid A, Parpia R. Relations between immigrant care workers and older persons in home and long-term care. Canadian Journal on Aging / La Revue canadienne du vieillissement. 2010;29:109-18.

9. Timonen V, Doyle M. Caring and collaborating across cultures? Migrant care workers' relationships with care recipients, colleagues and employers.

European Journal of Women's Studies. 2010;17(1):2541.

10. Walsh K, O’Shea E. Marginalised care: Migrant workers caring for older people in Ireland. Journal of Population Ageing. 2010;3(1):17-37.

11. Andrews M, Squire C, Tamboukou M (red.). Doing narrative research. London mfl.: Sage Publications; 2013.

12. Statistisk sentralbyrå (SSB). Tall tilsendt per epost 12.02.2016 fra Åsne Vigran, Seksjon for arbeidsmarkedsstatistikk. Oslo: Statistisk sentralbyrå; 2016.

13. Haavind H. Kjønn og fortolkende metode. Metodiske muligheter i kvalitativ metode. Oslo: Gyldendal Akademisk; 1999.

14. Kvale S. Det kvalitative forskningsintervju. Oslo: Ad Notam Gyldendal; 1997. 
15. Cohen AP, Rapport N. Introduction:

Consciousness in anthropology. I: Cohen AP, Rapport

N (red.). Questions of consciousness. London og New York: Routledge; 1995.

16. Meld. St. 29 (2012-2013) Morgendagens

omsorg. Oslo: Helse- og omsorgsdepartementet; 2013. 